\title{
Correction to: Gel electrophoresis of human sperm: a simple method for evaluating sperm protein quality
}

Fanny Jumeau ${ }^{1,2,3,6}$, Julien Sigala1,2,3, Francisco-Jose Fernandez-Gomez ${ }^{3}$, Sabiha Eddarkaoui ${ }^{3}$, Sophie Duban-Deweer ${ }^{4}$, Luc Buée ${ }^{3}$, Hélène Béhal ${ }^{5}$, Nicolas Sergeant ${ }^{3}$ and Valérie Mitchell ${ }^{1,2^{*}}$

\section{Correction to: Basic Clin Androl https://doi.org/10.1186/s12610-018-0076-0}

Following publication of the original article [1], the authors reported that the author given names and family names had been transposed. The author names in this correction article are presented correctly.

Fanny (Given name) Jumeau (Family name)

Julien (Given name) Sigala (Family name)

Francisco-Jose (Given name) Fernandez-Gomez

(Family name)

Sabiha (Given name) Eddarkaoui (Family name)

Sophie (Given name) Duban-Deweer (Family name)

Luc (Given name) Buée (Family name)

Hélène (Given name) Béhal (Family name)

Nicolas (Given name) Sergeant (Family name)

Valérie (Given name) Mitchell (Family name)

\section{Author details}

'EA 4308 - GQG - Gametogenesis and gamete quality, University of Lille, F-59000 Lille, France. ${ }^{2} \mathrm{CHU}$ Lille, Reproductive Biology - Spermiology CECOS Institute, F-59000 Lille, France. ${ }^{3}$ University of Lille, Institut National de la Santé et de la Recherche Medicale (INSERM), CHU Lille, UMR-S 1172 JPArc, F-59000 Lille, France. ${ }^{4}$ EA 2465 - LBHE Blood-Brain Barrier Laboratory, University of Artois, F-62307 Lens, France. ${ }^{5} \mathrm{CHU}$ Lille, EA 2694 - Santé publique: épidémiologie et qualité des soins, University of Lille, F-59000 Lille, France. ${ }^{6}$ Present address: Reproductive Biology Laboratory - CECOS, Rouen University Hospital, Rouen University, F-76031 Rouen, France.
Published online: 13 February 2020

\section{Reference}

1. Jumeau F, Sigala J, Fernandez-Gomez F-J, et al. Gel electrophoresis of human sperm: a simple method for evaluating sperm protein quality. Basic Clin Androl. 2018;28:10 https://doi.org/10.1186/s12610-018-0076-0.
The original article can be found online at https://doi.org/10.1186/s12610018-0076-0

* Correspondence: valerie.mitchell@chru-lille.fr

'EA 4308 - GQG - Gametogenesis and gamete quality, University of Lille, F-59000 Lille, France

${ }^{2} \mathrm{CHU}$ Lille, Reproductive Biology - Spermiology - CECOS Institute, F-59000 Lille, France

Full list of author information is available at the end of the article

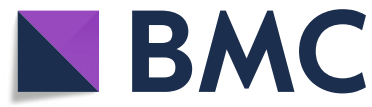

( $)$ The Author(s). 2020 Open Access This article is distributed under the terms of the Creative Commons Attribution 4.0 International License (http://creativecommons.org/licenses/by/4.0/), which permits unrestricted use, distribution, and reproduction in any medium, provided you give appropriate credit to the original author(s) and the source, provide a link to the Creative Commons license, and indicate if changes were made. The Creative Commons Public Domain Dedication waiver (http://creativecommons.org/publicdomain/zero/1.0/) applies to the data made available in this article, unless otherwise stated. 